\title{
DER KONKURS \\ DER GESELLSCHAFT MIT BESCHRÄNKTER HAFTUNG
}

\author{
VON \\ DR. IUR. WALTER LEHMANN.
}

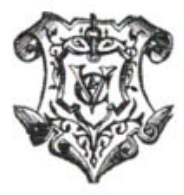

LEIPZIG

VERLAG VON VEIT \& COMP.

1913 
Leipziger juristische Inauguraldissertation. 